\title{
PENDAMPINGAN IMPLEMENTASI MANAJEMEN RISIKO COVID-19 DI TEMPAT BERIBADAH
}

\author{
HERRY ACHMAD BUCHORY ${ }^{1}$, RR. RACHMAWATI ${ }^{2}$ \\ Program Studi Magister Manajemen ${ }^{1}$, Program Studi Manajemen ${ }^{2}$ \\ Sekolah Tinggi Ilmu Ekonomi (STIE) Ekuitas Bandung \\ J1. PH.H. Mustofa 31, Kota Bandung 40124 \\ *e-mail: achmad.buchory@gmail.com
}

\begin{abstract}
The world is currently in shock with the emergence of the corona virus known as COVID-19. The virus, which was first discovered in the city of Wuhan, China at the end of December 2019, spreads quickly and has spread throughout the world, including Indonesia. The increasing growth of the corona virus has spread to various aspects of life, from the economic field to the religious aspect. Muslims who usually carry out various congregational prayers freely in mosques are now no longer happening, even mosques are considered as one of the clusters for the spread of the Covid-19 virus. Considering these conditions, we are called to provide assistance in implementing risk management in mosques by providing knowledge and understanding about the importance of prevention and risk management efforts and providing the equipment needed to support the implementation of risk management in places of worship. By assisting the implementation of this risk management, the awareness of the congregation can increase through the implementation of carrying out risk management practices on a regular and sustainable basis so that the prevention of the spread of the Covid-19 virus can be suppressed and religious activities can continue.
\end{abstract}

Keywords: Covid-19, Risk Management, Places of Worship

\begin{abstract}
ABSTRAK
Dunia saat ini digemparkan dengan munculnya virus corona yang dikenal dengan COVID-19. Virus yang pertama kali ditemukan di kota Wuhan, Cina pada akhir Desember 2019 ini menular dengan cepat dan telah menyebar ke seluruh dunia termasuk Indonesia. Pertumbuhan virus corona yang semakin meningkat telah menjalar ke berbagai sendi kehidupan mulai dari bidang ekonomi sampai dengan aspek keagamaan. Umat Islam yang biasanya menjalankan berbagai ibadah berjamaah di mesjid secara bebas saat ini tidak lagi terjadi bahkan mesjid dianggap sebagai salah satu cluster penyebaran virus Covid-19. Memperhatikan situasi tersebut kami merasa terpanggil untuk melakukan pendampingan implementasi manajemen risiko di Mesjid dengan cara memberikan pengetahuan dan pemahaman tentang pentingnya upaya pencegahan dan melakukan manajemen risiko dan memberikan peralatan yang dibutuhkan untuk mendukung terlaksananya implementasi manajemen risiko di tempat ibadah. Dengan dilakukannya pendampingan implementasi manajemen risiko ini, maka kesadaran para jemaah dapat meningkat melalui penerapan melakukan praktek-praktek manajemen risiko secara rutin dan berkelanjutan sehingga pencegahan penyebaran virus Covid-19 ini dapat ditekan dan kegiatan keagamaan tetap berjalan.
\end{abstract}

Kata Kunci: Covid-19, Manajemen Risiko, Tempat Beribadah 


\section{PENDAHULUAN}

Dunia saat ini sedang digemparkan dengan munculnya virus corona. Virus Corona atau severe acute respiratory syndrome coronavirus 2 (SARS-CoV 2) adalah virus yang menyerang sistem pernapasan. Penyakit karena infeksi virus ini disebut COVID-19. Virus Corona bisa menyebabkan gangguan pada sistem pernapasan, pneumonia akut, sampai kematian. Infeksi virus ini disebut COVID-19 yang pertama kali ditemukan di kota Wuhan, Cina, pada akhir Desember 2019. Virus ini menular dengan cepat dan telah menyebar ke seluruh dunia termasuk Indonesia. Data sampai dengan tanggal 03 Januri 2021 perkembangan virus corona Covid di Dunia jumlah orang positif 84.994.945 orang, meninggal 1.843.301 orang dan sembuh 60.097.168 orang.

(https://www.worldometers.info/coronavirus/)

Sedangkan di Indonesia sampai tanggal 03 Januari 2021 menunjukkan bahwa jumlah orang positif 765.350 orang, meninggal 22.734 orang dan sembuh 631.937 orang (https://infeksiemerging.kemkes.go.id/situasiinfeksi-emerging/situasi-terkiniperkembangan-coronavirus-disease-covid-1904-januari-2021). Di Jawa Barat jumlah orang positif 86.250 orang, meninggal 1.176 orang dan sembuh 72.914 orang. Sedangkan di kota Bandung jumlah orang positif 5.810 orang, meninggal 154 orang dan sembuh 5.160 orang (https://prfmnews.pikiranrakyat.com/jawa-barat/pr-

131209325/melonjak-lagi-positif-covid-19-dijawa-barat-hingga-minggu-3-januari-2021capai-86250-kasus)

Dengan jumlah pertumbuhan virus corona yang semakin meningkat, ternyata dampak wabah virus ini telah menjalar ke berbagai sendi kehidupan mulai dari bidang ekonomi sampai dengan aspek keagamaan. Umat Islam yang biasanya menjalankan berbagai ibadah berjamaah di mesjid secara bebas tanpa mengenal jumlah jamaah sebelum terjadi Covid 19 maka saat ini dibatasi sesuai anjuran pemerintah.

Di Kota Mekkah Saudi Arabia tepat nya di Masjidil Haram yang merupakan tempat keramaian untuk beribadah oleh umat Islam yang berasal dari berbagai negara, kini telah berkurang sangat drastis. Ibadah haji hanya diperbolehkan untuk para jemaah lokal yang berasal dari umat muslim sekitarnya dan beberapa negara yang diijinkan oleh Pemerintah Saudi Arabia. Tahun 2020 Indonesia tidak memberangkatkan Jemaah untuk beribadah haji karena larangan dari pemerintah Arabia Saudi yang berkeinginan menekan penyebaran visrus corona Covid 19. Kejadian tidak memberangkatkan ibadah haji ini mungkin kali pertama dalam sejarah umat muslim di Indonesia

Di dalam menghadapi wabah virus Covid-19 yang telah banyak merenggut ribuan bahkan jutaan orang dari nyawa manusia tersebut maka menuntut umat muslim untuk merubah perilaku dan tata cara dalam menjalankan ibadah termasuk beribadah di mesjid bagi umat Islam. Pemerintah melalui Kementerian Agama dan Majelis Ulama serta Satgas Penganggulangan Virus Covid 19 telah mengeluarkan berbagai anjuran dan himbauan kepada masyarakat tentang tata cara menjalankan ibadah di mesjid dengan mempertimbangkan protokol kesehatan. Artinya tetap menjalankan ibadah sesuai dengan agama dan kepercayaan namun berikhtiar untuk tetap menerapkan protokol kesehatan untuk meredam penyebaran virus Covid 19 tersebut dari kluster tempat beribadah khusunya dari mesjid-mesjid.

Mesjid AL-ASYIQIEN yang berlokasi di Jalan Komodor Supadio No. 105/72 RT 02/RW06 Kelurahan Husein Sastranegara Kecamatan Cicendo Kota Bandung, merupakan salah satu mesjid yang berlokasi di lingkungan penduduk padat dengan kapasitas sekitar 2000 jemaah sehingga para jemaahnya berpotensi untuk terpapar virus tadi.

Para Jemaah mengetahui tentang sangat berbahayanya dampak dari adanya virus 
Covid 10 yang begitu besar risikonya. Namun kondisi ini tidak mengurangi ketaaatan dan keyakinan beragama para Jemaah, bahkan mereka sangat percaya bahwa terjadinya musibah ini karena kehendak Allah SWT. Oleh karena itu mereka percaya bahwa akhirnya musibah pandemik virus Corona 19 tersebut akan berhenti pada waktunya karena kehendak Allah SWT juga. Kegiatan ibadah pada saat awal-awal terjadi musibah tersebut dan memperhatikan anjuran dari Pemerintah dan Majelis Ulama Indonesia maka muslimin melaksanakan ibadahnya di rumah masingmasing. Pelaksanaan sholat berjamaah dan sholat-sholat lainnya termasuk ritual keagamaan yang biasanya dilaksanakan di mesjid seperti pengajian rutin malam jumat, sementara diberhentikan. Namun dengan keyakinan yang kuat dan ketaatan beribadah kepada Allah SWT, para jemaah melaksanakan kembali ritual keagamaannya seperti sebelum terjadinya penyebaran virus corona Covid 19, meskipun dengan tatacara yang sedikit berbeda. Melihat situasi seperti itu maka kami merasa terpanggil untuk memberikan pengetahuan dengan cara memberikan sosialisasi dan pemahaman melakukan manajemen risiko yang mungkin timbul akibat dari dampak pandemik virus corona (Covid-19) ini. Melalui program pengabdian masyarakat, saya akan melakukan pendampingan implementasi manajemen risiko di tempat ibadah dan memberikan beberapa peralatan yang dibutuhkan untuk mendukung terlaksananya implementasi manajemen risiko ini.

Berdasarkan hasil hasil pra-survey dan memperhatikan permasalahan yang dihadapi sebagaimana dijelaskan di atas maka masalah utama yang dialami oleh mitra saat ini adalah sebagai berikut:

1. Masih antusiasnya jamaah untuk melaksanakan ibadah di mesjid ALASYIQIEN secara berjamaah meskipun sedang terjadi pandemik Virus Corona atau Covid 19 dengan mengabaikan protokol kesehatan
2. Masih rendahnya pemahaman dan kesadaran jamaah tentang begitu besarnya dampak dan risiko yang dihadapi oleh siapa saja yang terpapar Virus COVID 19 di tempat ibadah termasuk di mesjid ALASYIQIEN

3. Terbatasnya sarana prasarana yang dimiliki oleh mesjid AL-ASYIQIEN untuk mendukung protokol Kesehatan yang dianjurkan oleh pemerintah berisi uraian semua.

\section{METODE PELAKSANAAN}

Metode pelaksanaan kegiatan pengabdian masyarakat ini fokus pada implementasi manajemen risiko di tempat ibadah khususnya mesjid AL-ASYIQIEN yang berlokasi Jalan Komodor Supadio No. 105/72 RT 02/RW06 Kelurahan Husein Sastranegara Kecamatan Cicendo Kota Bandung, sehubungan dengan terjadinya pandemik virus Covid 19.

Secara umum metode yang dilakukan adalah sebagai berikut:

1. Mempelajari dan menyiapkan materi yang akan disampaikan dalam program pengabdian bersumber dari berbagai referensi dan informasi yang relevan sesuai dengan tujuan pengabdian

2. Penyampaian materi tentang konsep dan pentingnya manajemen risiko secara umum, manajemen risiko di tempat beribadah dilakukan tanggal 09 Mei 2021 dengan metode ceramah, diskusi kelompok dan tanya jawab. Metode ceramah dilakukan dengan cara menyampaikan materi sosialisasi kepada peserta secara langsung atau dengan lisan. Metode ini sifatnya praktis dan efisien dibantu dengan menggunakan peralatan komputer lap-top, in-focus dan sound system. Sedangkan diskusi kelompok adalah proses yang teratur yang melibatkan sekelompok orang di wajah informal untuk menghadapi interaksi dengan berbagai pengalaman atau informasi, kesimpulan atau solusi untuk masalah (Usman, 2015:94). Seluruh 
peserta sosialisasi baik pemateri maupun peserta sosialisasi menerapkan protokol Kesehatan antara lain peserta jumlahnya dibatasasi dan dinyatakan sehat, sosialisasi dilaksanakan di ruangan yang tidak dipasang karpet, duduk dengan menjaga jarak dan memakai masker selama kegiatan berlangsung.

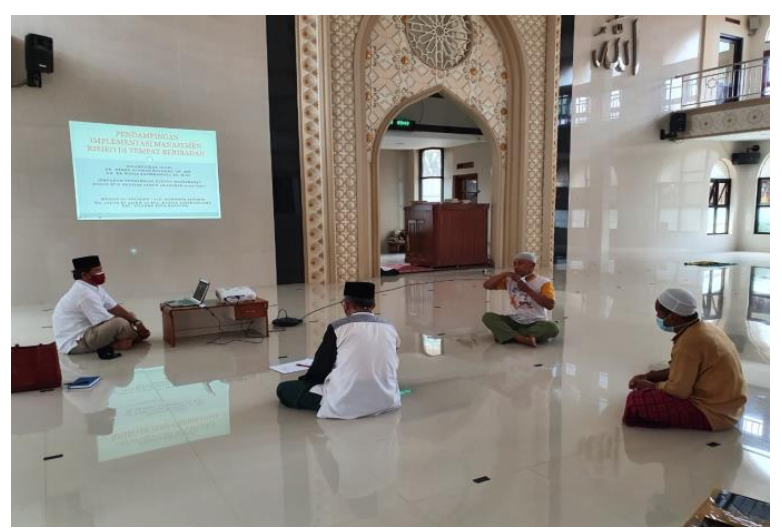

Gambar 1. Sosialisasi materi tentang konsep dan pentingnya manajemen risiko secara umum

3. Melakukan pelatihan dan simulasi penggunaan electric sprayer yang merupakan alat penyemprotan cairan isinfektas yang dapat digunakan baik secara manual maupun otomatis. Dua orang peserta (santri) yang bertugas menjaga kebersihan mesjid dilatih cara penggunaan alat tersebut, kemudian alat tersebut diisi air dan dicoba untuk melakukan penyemprotan.

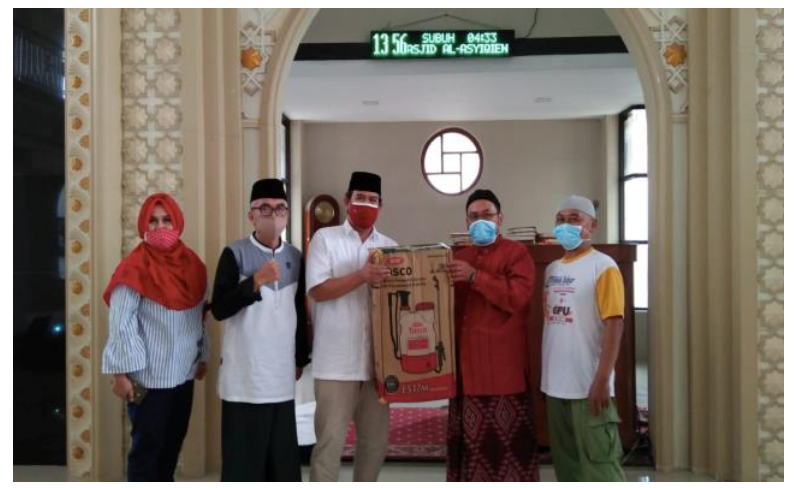

Gambar 2. Pelatihan dan simulasi penggunaan electric sprayer
4. Memotivasi mitra dan para jemaah masjid tentang pentingnya penerapan manajemen risiko di tempat ibadah ini secara berkelanjutan dan menekankan agat peralatan yang merupakan bantuan dalam program pengabdian ini digunakan secara teratur, dipelihara dan dijaga dengan baik.

5. Mendampingi implementasi manajemen risiko di tempat ibadah khususnya di mesjid AL-ASYOQIEN.

6. Melakukan evaluasi terhadap pelaksanaan pendampingan imple-mentasi manajemen risiko di tempat beribadah khususnya di mesjid AL-ASYIQIEN.

\section{HASIL DAN PEMBAHASAN}

Kegiatan pengabdian pada masyarakat yang dilakukan adalah berupa pendampingan implementasi manajemen risiko di tempat beribadah dan pemberian alat untuk mendukung kelancaran kegiatan implementasi tersebut. Hasil dari kegiatan pengabdian kepada masyarakat dan sesuai dengan metode yang digunakan, maka diperoleh hasil sebagai berikut:

1. Meningkatkan kesadaran dan pemahaman mitra setelah mengikuti sosialisasi tentang begitu besarnya dampak dan risiko yang dihadapi oleh siapa saja yang terpapar Virus COVID 19 yang sampai saat ini belum ditemukan vaksin serta obat sehingga virus tersebut dapat menyerang semua orang, kapan saja dan dimanapun tempatnya termasuk di tempat beribadah khususnya di Mesjid AL-ASYIQIEN.

2. Mitra melaksanakan upaya pencegahan untuk mengurangi risiko melalui perilaku hidup sehat dan melaksanakan upayaupaya protokol kesehatan yang dibutuhkan di tempat beribadah khususnya di Mesjid AL-ASYIQIEN.

Hal ini dibuktikan dengan berubahnya perilaku para Jemaah mesjid yang akan melaksanakan ibadah di mesjid ALASYIQIEN, sebelum dan berada di lingkungan bangunan Mesjid, jamaah 
melakukan kegiatan-kegiatan sebagai berikut:

- Menggunakan masker pada saat memasuki area mesjid

- Cuci tangan dengan sabun di tempat cuci tangan yang telah disediakan,

- Menyimpan sandal dengan tertib

- Membawa peralatan ibadah sendiri

- Beribadah/Sholat dengan menggunakan peralatan sendiri

- Menjaga jarak pada saat melak-sanakan sembahyang

- Tidak bersalaman setelah selesai melaksanakan sholat

- Segera meninggalkan mesjid setelah selesai ibadah

3. Tersedianya beberapa peralatan yang dibutuhkan di tempat ibadah khususnya di Mesjid AL-ASYIQIEN untuk mengantisipasi timbulnya risiko yang disebabkan oleh Virus Covid 19 tersebut, dengan memasang tempat cuci tangan, tempat wudhu yang menerapkan jaga jarak, melakukan penyemprotan disinfektan secara teratur dengan menggunakan peralatan bantuan yang diberikan pada pengabdian masyarakat ini.

4. Dengan telah dilakukannya pendampingan implementasi manajemen risiko ini, mitra dengan kesadaran sendiri dapat melakukan praktek-praktek penerapan manajemen risiko secara rutin dan berkelanjutan di Mesjid AL-ASYIQIEN sehingga salah satu upaya pencegahan penyebaran virus Covid 19 ini dapat ditekan.

\section{KESIMPULAN}

1. Meningkatnya kesadaran dan pemahaman para jemaah tentang begitu besarnya dampak dan risiko Virus COVID 19 yang sampai saat ini belum ditemukan obatnya.

2. Meningkatnya kesadaran dan kepedulian para jemaah untuk mengurangi risiko Covid-19 dengan melakukan kegiatankegiatan seperti memakai berbagai alat pelindung diri (APD), berperilaku hidup sehat, dan selalu menerapkan protocol kesehatan.

3. Meningkatnya kesadaran dan kepedulian tentang pentingnya kebersihan tempat beribadah dengan menggunakan peralatan yang dimiliki dan dilakukan secara kontinyu.

\section{UCAPAN TERIMA KASIH}

Pada kesmpatan ini kami sampaikan ucapan terima kasih kepada Ketua STIE Ekuitas yang telah memfasilitasi kegiatan sehingga kami dapat melaksanakan kegiatan pengabdian kepada masyarakat ini. Selain itu kami juga menyampaikan terima kasih dan penghargaan yang tinggi kepada Ketua DKM Mesjid AL-ASYIQIEN yang telah memberikan kesempatan kepada kami untuk melaksanakan kegiatan pengabdian ini, mudah-mudahan bermanfaat.

\section{DAFTAR PUSTAKA}

[1] Buchory, Herry Achmad, 2016. Bahan Kuliah Manajemen Risiko, STIE Ekuitas, Bandung.

[2] Dewan Kesejahteraan Mesjid AlMuhajirin (2020). Manajemen Risiko Covid-19 di Masjid Al-Muhajirin, Pondok Mekarsari Permai, Depok.

[3] Hanafi, Mamduh (2016), Manajemen Risiko, STIM YKPN.

[4] Kementrian Kesehatan Republik Indonesia dan Dewan Masjid Indonesia (2020). Jaga Kebersihan Masjid dan Mushalla Dari COVID-19, Brosur.

[5] Kuswara, Asep (2020). Persiapan PSBB Kota Bandung, Dinas Perhubungan Kota Bandung.

[6] Lam, James (2013). Enterprise Risk Management John Wiley and Sons.

[7] Razi, Fakhrur (2020). Bunga Rampai COVID-19: Buku Kesehatan Mandiri Untuk Sahabat, Perhimpunan Profesional Kesehatan Muslim Indonesia, Depok. 
[8] Usman, Moh. Uzer (2015). Menjadi Guru Profesional, Bandung: Remaja Rosdakarya.

[9] Walikota Bandung, Peraturan Nomor 37 Tahun 2020 Tentang Pedoman Pelaksanaan Adaptasi Kebiasaan Baru Dalam Rangka Pencegahan dan Pengendalian Corona Virus Disease 2019 (Covid-19).

[10] Widyaningrum, Nurvika, dkk. (2020). Serba Covid, Cegah COVID-19, Sehat Untuk Semua, Badan POM.

[11] Zakaria, A. (2020). Sikap Seorang Muslim Dalam Menghadapi Virus Corona, IBN Azka Press. ISBN 978 $979-3759$.

[12] Worldometer. "COVID-19 CORONAVIRUS PANDEMIC". 2021. [Online]. Available: https://www.worldometers.info/coronav irus/ [Accessed: September 27, 2021]

[13] RM. "Situasi Terkini Perkembangan Coronavirus Disease (COVID-19) 04 Januari 2021". 2021. [Online]. Available:

https://infeksiemerging.kemkes.go.id/sit uasi-infeksi-emerging/situasi-terkiniperkembangan-coronavirus-diseasecovid-19-04-januari-2021 [Accessed: September 27, 2021]

[14] Rian Firmansyah. "Melonjak Lagi! Positif Covid-19 di Jawa Barat Hingga Minggu 3 Januari 2021 Capai 86.250 Kasus". 2021. [Online]. Available: https://prfmnews.pikiranrakyat.com/jawa-barat/pr131209325/melonjak-lagi-positif-covid19-di-jawa-barat-hingga-minggu-3januari-2021-capai-86250-kasus [Accessed: September 27, 2021] 